\title{
加工せるアルミニゥム合金の軟化について (1)
}

\section{Al- Pb 合金:の 実 験*}

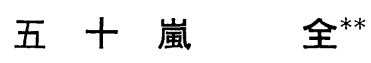

On the annealing of cold-rolled aluminium alloy (1)

(UDG 669.71-12: 621.785.3)

Study on $\mathrm{Al}-\mathrm{Pb}$ alloys

IGARASHI Tamotu**

This is a report on the annealing of cold-rolled high-purity $\mathrm{Al}-\mathrm{Pb}$ alloys. By measuring the breadth of $\mathrm{X}$ ray rocking curve which was diffracted from a poly-crystal, the auther observed the dislocation movement in softening, recovery and recrystallization of $\mathrm{Al}-\mathrm{Pb}$ alloys. The result was that in case of cold-worked and then annealed metals of $\mathrm{Al}-\mathrm{Pb}$ alloys the (220) planes rocking curve breadth did not decrease so rapidly as high-purity aluminium. The integral breadth of (222), (422) planes, sometimes registered different movements from other planes.

(Received July 18, 1963)

\section{1. ま え がき}

金属結晶の塑性加工や再結晶過程の機構については, これを転位でもつて説明つけるべく研究されている。転 位の観察には比重や電気抵抗の測定, 腐食孔や電子顕微 鏡での直接観察などいろいろと研究されているが, Debye-Scherrer環の幅での研究は少なくあまり実験され ていない。Deby-Scherrer 環の幅での研究1)も小数の面 だけの測定が行なわれている。そこで著者は測定面を多 くし, 積分幅と硬さの変化を測定し, あわせて積分反射 量の変化の動きも測定してアルミニウムに固溶元素を添 加した場合の変り具合を測定することにより，再結晶機 構の一端を究明した。またX線透過写真は結晶粒の形態 を見るためにこれを撮り，次記の実験を進めた。この論 文では鉛を添加した場合の実験結果を記す。

\section{2. 実 験 方 法}

2.1 溶解, 鍛造, 溶体化処理, 分析試料
高純度アルミニウムを $1 \mathrm{~kg}$ 溶解, 電解鉛を添加, 直径 $70 \mathrm{~mm}$, 高さ $100 \mathrm{~mm}$ の金型に鋳造, 鋳塊 A をつくる。同 様にして鋳塊B もつくる。A $\mathrm{Pb}$ を目標に鉛を添加した。結晶粒を微細化するため十 分鍛造を行ない，偏析部をさけるため縦に 2 つに切り, フライス盤で表面を削り $20 \times 40 \times 150 \mathrm{~mm}$ の大きさ 2 つ, 計 4 つに仕上げる。次にマッフル炉で $650^{\circ} \mathrm{C}, 100 \mathrm{hr}$ 溶 体化処理後水冷した。

この試料を同一方向に厚さ $3.05 \mathrm{~mm}$ まで圧延し，鋳塊 の上部と下部，すなわち圧延板の前部と後部より分析試 料を取り分析を行なつた。分析は住友軽金属工業(侏)の御 厚意によるもので, 結果は Table 1 である。

\section{2 焼なまし, 圧延加工}

これより $90 \%$ 圧延用はそのまま，56\% 圧延用は厚さ $0.71 \mathrm{~mm}$ まで, $15 \%$ 用は $0.31 \mathrm{~mm}$ まで同一方向に圧延し $\mathrm{NaNO}_{3}: \mathrm{NaNO}_{2}=1: 1$ の塩谷で $650^{\circ} \mathrm{C}$ で $15 \mathrm{sec}$ 焼な まし後, 水冷した。そのときの結晶粒は Photo. 1 に示 した。

Table 1 Chemical analysis of slab.

\begin{tabular}{|c|c|c|c|c|c|c|c|c|c|c|c|}
\hline \multirow{2}{*}{ Ingot } & \multirow{2}{*}{ Part } & \multicolumn{10}{|c|}{ Composition } \\
\hline & & $\mathrm{Si}$ & $\mathrm{Fe}$ & $\mathrm{Cu}$ & $\mathrm{Mg}$ & $\mathrm{Mn}$ & $\mathrm{Zn}$ & $\mathrm{Ti}$ & & $\mathrm{b}$ & $\mathrm{Al}$ \\
\hline \multirow{2}{*}{$\mathrm{A}$} & Top & $0.001 w t \%$ & $0.002 w t \%$ & $0.001 \mathrm{wt} \%$ & $\operatorname{tr}$ & $\operatorname{tr}$ & $\operatorname{tr}$ & $\operatorname{tr}$ & $0.046 w t \%$ & 0.006 at $\%$ & remainder \\
\hline & Bottom & " & " & " & $" \prime$ & $" \prime$ & $"$ & " & $0.054 w t \%$ & 0.007 at $\%$ & " \\
\hline \multirow{2}{*}{$\mathrm{B}$} & Top & " & " & " & " & " & $"$ & " & $0.130 w t \%$ & 0.017 at $\%$ & $"$ \\
\hline & Bottom & " & " & " & " & " & " & " & $0.144 w t \%$ & $0.019 a \mathrm{at} \%$ & " \\
\hline
\end{tabular}

* 軽金属研究会第22回（昭和37年 6 月 6 日）春期大会に発表

** 秋田大学鉣山学部 Faculty of mining, Akita Univ. 
90\% 圧延用の焼なまし試料は同一方向に 8 回の roll pass で $0.30 \mathrm{~mm}$ まで $90.2 \%$ 圧延, $56 \%$ 圧延用の焼なま し試料は同一方向に 4 回の roll pass で $0.31 \mathrm{~mm}$ まで 56.3 $\%$ 圧延，15\%圧延用の試料は同一方向に 2 回の roll pass で $14.9 \%$ 圧延, 圧延板の前部後部は切りすて, 中央部よ り続けて $40 \times 40 \mathrm{~mm} の$ 試料を取る。

\section{3 焼なまし実験}

試料の隅に小穴をあけてアルミニウム線でつるし， 塩溶で焼なましを行ない，温度差で試料が曲らない程度

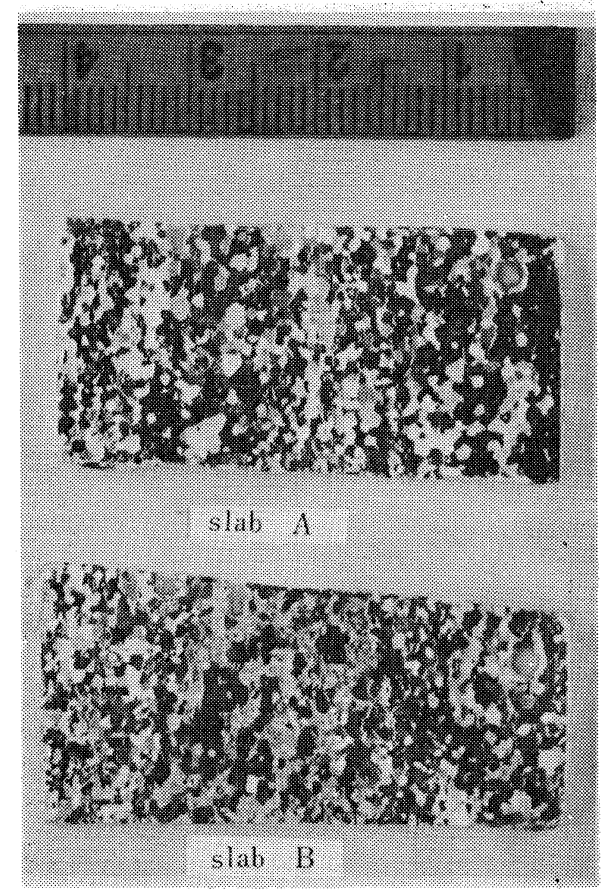

Photo. 1 Grains in specimens before cold rolling.
に急冷した。焼なましおよび焼なまし後の測定は Table 2 亿示した。

\section{4 硬さの測定}

硬さは明石製マイクロビッカース硬さ計を用い，荷重 は $100 \mathrm{~g}$ を使用，荷重時間は $15 \mathrm{sec}$ ，圧延面上で圧延方向 と直角方向に点々と 5 力所，また反対側で同様 5 力所, 合計10力所測定しその平均值を取り, 測定值の上限下限 値を示した。

\section{$2.5 \times$ 線 測 定}

$\mathrm{X}$ 線写真は $\mathrm{Cu}$ 対陰極で $\mathrm{Ni}$ フイルターを使用せずに 透過 Debye-Scherrer 写真を撮つた。

積分幅および積分反射は高純度アルミニウムの場合と 同様に行なつたが，一応次に測定条件を記す。島津自記 $\mathrm{X}$ 線分析装置, GX-2B 型を使用。試料は見掛けの結晶 粒を増すためにユニバーサル試料台で回転, 背面反射法 で測定した。X線管の対陰極は $\mathrm{Cu}$, 管電圧 $35 \mathrm{kV}$, 管電流 $17 \mathrm{~mA}, \mathrm{Ni}$ フイルターを使用, 検出管は G.M. 計数管, 計 数管電圧 $1500 \mathrm{~V}$, 時定数 $2.5 \mathrm{sec}$, 計数管走查速度 $0.5 \% \mathrm{sec}$,

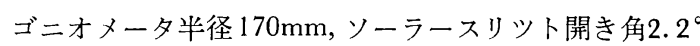
分散スリット $2 \mathrm{~mm}$, 中間スリット $8 \mathrm{~mm}$, 検出スリット $0.3 \mathrm{~mm}$, chart 送り速度 $5 \mathrm{~mm} / \mathrm{min}$ 。

積分幅は

$$
\left\{\int_{\theta_{1}}^{\theta_{2}} I d \theta-\int_{\theta_{1}}^{\theta_{2}} I_{b} d \theta\right\} / 1.5\left(I_{\max }-I_{b}\right)
$$

を計算した。図(Fig. 3〜6) ではグラフの高さが過大に なるのを避けるために，(220)面では23，(311) 面では26, (222)面では25，(400)面では22.5, (331)面では26, (420) 面では 27.5，(422）面では33をそれぞれ減じて示した。 式中 $\int_{\theta_{1}}^{\theta_{2}} I d \theta$ は Debye-Scherrer 環を含み $300 \mathrm{sec}$ 走

Table 2 Experimental procedure.

\begin{tabular}{|c|c|c|c|c|c|c|c|c|c|c|c|c|c|c|c|c|c|c|}
\hline \multirow{2}{*}{$\begin{array}{c}\text { Retuction } \\
(\%)\end{array}$} & \multirow{2}{*}{$\left|\begin{array}{l}\text { Annealing } \\
\text { temp. }\left({ }^{\circ} \mathrm{C}\right)\end{array}\right|$} & \multirow{2}{*}{ Bath } & \multicolumn{14}{|c|}{ Annealing time } & \multirow[b]{2}{*}{$2 \mathrm{hr}$} & \multirow[b]{2}{*}{$4 \mathrm{hr}$} \\
\hline & & & as rollled & $1^{\prime \prime}$ & $2^{\prime \prime}$ & $4^{\prime \prime}$ & $8^{\prime \prime}$ & $15^{\prime \prime}$ & $30^{\prime \prime}$ & $1^{\prime}$ & 2 & $4^{\prime}$ & $8^{\prime}$ & 15 & 30 & $1 \mathrm{hr}$ & & \\
\hline 90 & $\begin{array}{l}160 \\
140 \\
120\end{array}$ & oil & $\oplus$ & $\begin{array}{l}\ominus \\
\ominus\end{array}$ & $\begin{array}{l}\Theta \\
\oplus\end{array}$ & $\begin{array}{l}\oplus \\
\oplus \\
\oplus\end{array}$ & $\begin{array}{l}\Theta \\
\Theta \\
\Theta\end{array}$ & $\begin{array}{l}\Theta \\
\oplus \\
\Theta\end{array}$ & $\begin{array}{l}\ominus \\
\ominus \\
\Theta\end{array}$ & $\begin{array}{l}\Theta \\
\oplus \\
\Theta\end{array}$ & $\begin{array}{l}\ominus \\
\ominus \\
\Theta\end{array}$ & $\begin{array}{l}\ominus \\
\oplus \\
\ominus\end{array}$ & $\begin{array}{l}0 \\
0 \\
\ominus\end{array}$ & $\begin{array}{l}0 \\
0 \\
\ominus\end{array}$ & $\begin{array}{l}\oplus \\
\oplus \\
0\end{array}$ & 0 & $\oplus$ & \\
\hline 56 & $\begin{array}{l}300 \\
280 \\
260\end{array}$ & $\begin{array}{l}\mathrm{KNO}_{3}-\mathrm{Na} \\
\mathrm{NO}_{3}\end{array}$ & $\oplus$ & & & $\begin{array}{l}\oplus \\
\oplus \\
\oplus\end{array}$ & $\begin{array}{l}\ominus \\
\Theta \\
\oplus\end{array}$ & $\begin{array}{l}\Theta \\
\Theta \\
\Theta\end{array}$ & $\begin{array}{l}\Theta \\
\Theta \\
\oplus\end{array}$ & $\begin{array}{l}\Theta \\
\Theta \\
\Theta\end{array}$ & $\begin{array}{l}\ominus \\
\Theta\end{array}$ & $\begin{array}{l}\ominus \\
\ominus \\
\oplus\end{array}$ & $\begin{array}{l}\Theta \\
\Theta\end{array}$ & $\begin{array}{l}\ominus \\
\ominus \\
\oplus\end{array}$ & $\begin{array}{l}0 \\
0\end{array}$ & $\begin{array}{l}\oplus \\
\oplus \\
\oplus\end{array}$ & & \\
\hline 15 & $\begin{array}{l}300 \\
280 \\
260\end{array}$ & $\begin{array}{l}\mathrm{KNO}_{3}-\mathrm{Na} \\
\mathrm{NO}_{3}\end{array}$ & $\begin{array}{l}\oplus \\
\oplus \\
\oplus\end{array}$ & & $\begin{array}{l}\Theta \\
\ominus \\
\ominus\end{array}$ & $\begin{array}{l}\oplus \\
\oplus \\
\oplus\end{array}$ & $\begin{array}{l}\Theta \\
\Theta \\
\Theta\end{array}$ & $\begin{array}{l}\Theta \\
\ominus \\
\ominus\end{array}$ & & $\begin{array}{l}\oplus \\
\oplus \\
\oplus\end{array}$ & & $\begin{array}{l}0 \\
0 \\
0\end{array}$ & & $\begin{array}{l}\Theta \\
\Theta \\
\Theta\end{array}$ & $\begin{array}{l}0 \\
0 \\
0\end{array}$ & $\begin{array}{l}\Theta \\
\Theta \\
\Theta\end{array}$ & $\begin{array}{l}0 \\
0 \\
0\end{array}$ & $\begin{array}{l}\oplus \\
\oplus \\
\oplus\end{array}$ \\
\hline
\end{tabular}

0 : Measued by the micro--vickers hardness.

$\Theta$ : Measued by the micro-vickers hardness, diffracted X-ray intensity and Debye-Scherrer line broadening.

$\oplus$ : Measued by the above mentioned methods and transmission Debye-Scherrer photograph. 
査, すなわち $\theta_{2}-\theta_{1}=2.5^{\circ}$ の角度内で計数した值，ただ し（422）面では $500 \mathrm{sec}$ 走査，すなわち $\theta_{2}-\theta_{1} \fallingdotseq 4^{\circ}$ の角 度内を計数した count 数である。 $\int_{\theta_{1}}^{\theta_{2}} I_{b} d \theta$ は上記角度内 でのBack-ground。 $I_{m a x}$ は自記記録紙上の最高值の読み， すなわち時定数 $2.5 \mathrm{sec} の$ 場合の $1 \mathrm{sec}$ 間の最高值， $I_{b}$ は $1 \mathrm{sec}$ 間の Back ground. 1.5は $\int I_{k \alpha 2} d \theta / \int I_{k \alpha 2} d \theta=0.46$ の関係と $k_{\alpha 1}$ と $k_{\alpha 2}$ による反射線の強度の Profile はそれ ぞれ相似であるとみなし近似的に 1.5 という数をだした。 上記の積分幅はStokesの方法で決定し角度の単位で表わ すところであるが，簡単に粗らい近似的法を用いたので 角度の単位はつけなかつた。しかしこれは積分幅の増減 を見るには十分な表示法である。

積分反射量は $\left\{\int_{\theta_{1}}^{\theta_{2}} I d \theta-\int_{\theta_{1}}^{\theta_{2}} I_{b} d \theta\right\}$ を用いた。

G.M. 管の Counting loss の補正は行なわなかつた。

\section{3. 実 験 結 果}

Fig. 1, 2 は硬さ測定值の上限, 下限および平均值と, X 線透過回折写真による再結晶状態を示したものである。

Fig. 3,4,5, および 6 は積分幅の測定值を示したもの でありFig. 7 は積分反射量測定值の一例を示したもので ある。

Fig. 1 より 90\%圧延の試料では圧延時にすでに再結晶 粒ができており (Photo. 2)軟化が進まない間は写真で判 別できるほどの結晶粒の変化は見られない(Photo. 3) 写 真に現われるだけの結晶粒の変化，すなわち再結晶がは じまると軟化が起り，硬さの值のばらつきが見られる。 これは再結晶粒のところとそうでないところの硬さの測 定によるものと考えられる。すべての部分が殆んど再結 晶し終ると, 硬さのばらつきがなくなり写真もほとんど 再結晶粒の斑点だけになり，160 $\mathrm{C}$ では $15 \sim 30 \mathrm{sec}$ で, $140^{\circ} \mathrm{C}$ では約 $30 \mathrm{sec}$ で, $120^{\circ} \mathrm{C}$ では $4 \mathrm{~min}$ で硬さが20以下 になる。

Fig. 2 より 56\%圧延の試料では測定温度が高すぎたた めか再結晶および軟化の変化が非常に速く進み $300^{\circ} \mathrm{C}$, $280^{\circ} \mathrm{C}$ 焼なましでは $8 \mathrm{~min}$ ほどで硬度数 17〜18になり， 硬さのばらつきもなくなつたが，260 $\mathrm{C}$ 焼なましでは $1 \mathrm{hr}$ 焼なまし後も硬さは20以下にならなかつた。しかし硬さ のばらつきは再結晶進行時の上限, 下限值の開きよりも 少なくなり，15\%圧延材焼なましの場合のばらつきに近 くなつた。15\%圧延の試料では写真には Debye-Scherrer 環よりも asterism が主に見られ，硬度数も30近くにな つただけで，軟化はまず polygonization が行なわれる ことにより軟化が進み，1 min 焼なまし後の写真にも再 結晶粒の斑点は見られず硬度数は 25 近くとなる。次に再 結晶粒ができて軟化が進んで行くのであるが, 高加工度
の試料に比べ硬さの上限，下限の差が少ないまま軟化し $300,280 お よ ひ ゙ 260^{\circ} \mathrm{G}$ での焼なましでは $4 \mathrm{hr}$ 後には硬さ のばらつきが非常に少なくなるが，再結晶は終らず硬さ も20以上である。

積分幅の変化は硬さの軟化とともに減少しているが, 軟化曲線より変動が多い。これは再結晶過程において格 子面間隔の大小の分布の多少を示すもので, 硬さより見 た結晶組織には変りがなくとも, 格子面間隔より見た組 織には多くの変化が現われていることを示している。

（220）面の積分幅の変化は90\%圧延では高純度アルミ ニウムの場合と同じく変化が非常に少ないが，高純度ア ルミニウムのように急減し，あと変化を示さない状態で はなく，軟化とともにわずか減少している。56\%圧延の 試料では as rolled でも(220)面の積分幅はたいして増加 していない。

（222）面はすべり面であるためか再結晶後も他の面に 変化がなくとも積分幅が広くなることがあつた（Fig. 4， $\mathbf{5 , 6 )}$ 。この変化は高純度アルミニウムの場合 ${ }^{(2)} に も$ 見ら れた。この変化を焼なまし時間の前後に対する変化より 見ると, どの指数の面も増加となるものは増加となり減 少となるものは減少となり，だいたい似た傾向を示すも のであるが，(222）面はそれがとくに変つており, 次に （422）面が変つた結果を示した。（422）面の例として Fig. 4 の $4^{\prime \prime} ， 1^{\prime} ， 90 \%$ 圧延 $120^{\circ} \mathrm{C}$ 焼なましの $15^{\prime \prime} ， 56 \%$ 圧 延 $300^{\circ} \mathrm{C}$ 焼なましの 4"，Fig. 6 の15”，30”などである。

積分反射量の変化は $90 \%$ 圧延の試料では（311）面の反 射量が最初非常に多いが再結晶粒ができるとともに大き く減少している。その外に (422) 面でわずか減少を示し ているのと (400) 面の反射量増加が $160 ， 140$ およ゙ 120 ${ }^{\circ} \mathrm{C}$ 焼なましの共通した傾向となつている。(Fig. 7)

$56 \%$ 圧延の試料では焼なまし時間で非常に反射量の違 らところがあるが，これは他の焼なまし温度での変化状 態と共通性がなく，その試料だけの変化で，写真より見 られるように加工前の結晶粒に影響されるもので, 加工 前の結晶粒が大き過ぎたためと思われる。この影響は加 工度が少ないほど大きく, $15 \%$ 圧延の試料では写真にも はつきり現われ，変化は非常に大きく増減の傾向の識別 は不可能な状態となつて現われた。これなど特異な変化 を除き変化の傾向を見ると $56 \%$ 圧延の試料では $90 \%$ 圧延 の試料のように特定の面だけがはつきりした増減を示す 傾向は見られなかつた。

高純度アルミニウムの場合に比べて結晶の方向性，す なわち(311) 面の反射量が特に多かつた。また板の厚さ が違うため熱容量が少ないためか再結晶変化が高純度ア ルミニウムより少し速いように思われた。実験全体より 鉛の添加量の多少によるはつきりした違いは見られなか つた。 


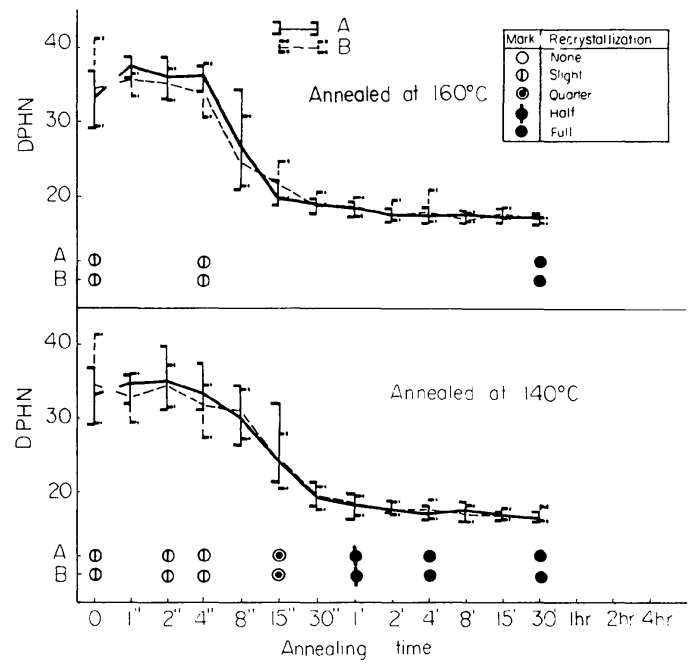

Fig. 1 Softening curves and degree of recrystallization determined by Debye-Scherrer patterns of $\mathrm{Al}-\mathrm{Pb}$ alloys cold rolled 90 pct. The micro-hardness numbers (DPHN) are mean values of ten readings.

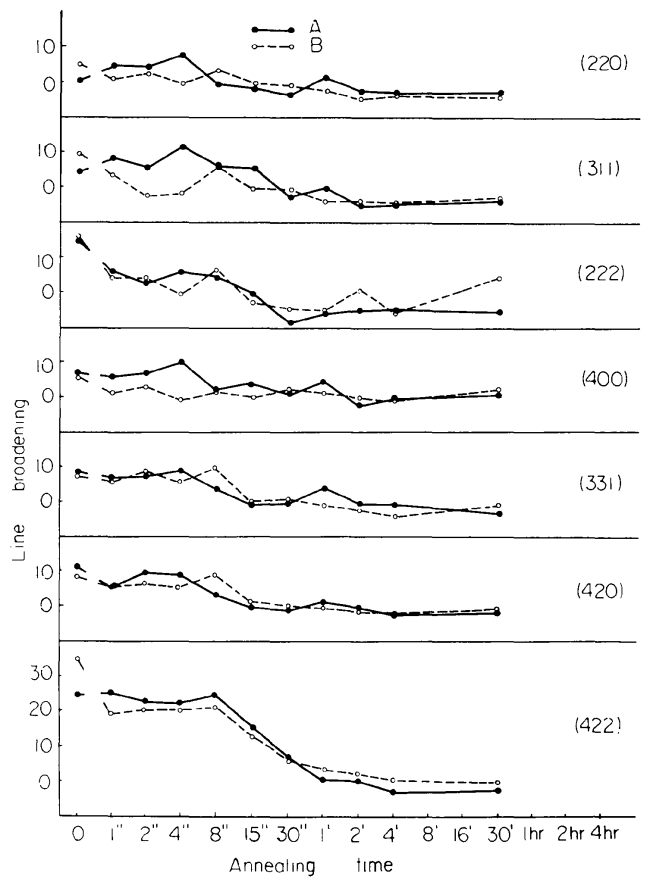

Fig. 3 Line broadening curves at $160^{\circ} \mathrm{C}$ in $\mathrm{Al}-\mathrm{Pb}$ alloys cold rolled 90 pct. The line broadening is the ratio of the integrated intensity and the maximum peak, corrected for back-ground intensity.

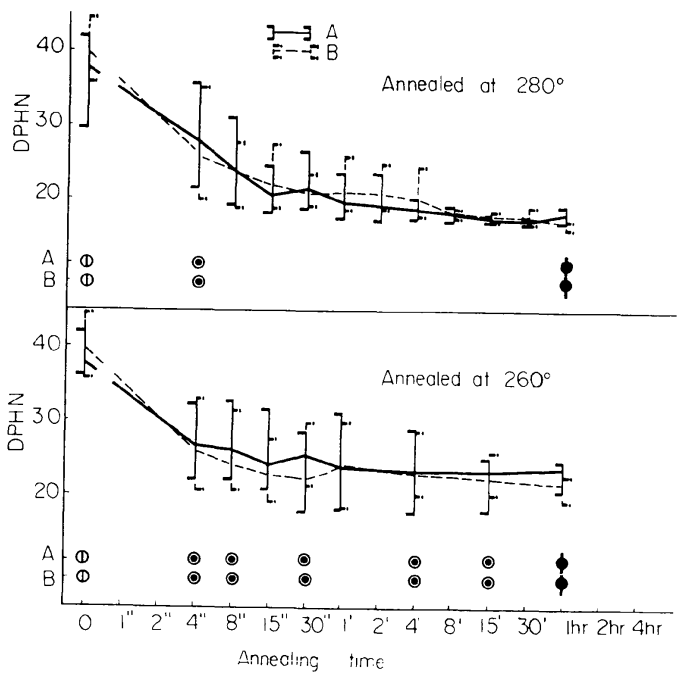

Fig. 2 Softening curves and degree of recrystallization determined by Debye-Scherrer patterns of $\mathrm{Al}-\mathrm{Pb}$ alloys cold rolled 56 pct. The micro-hardness numbers (DPHN) are mean values of ten readings.

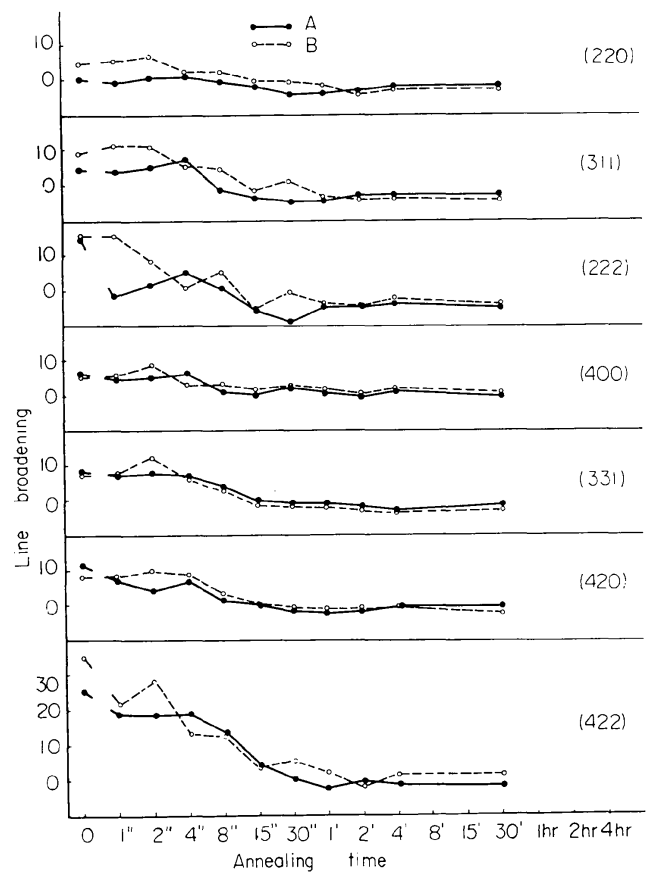

Fig. 4 Line broadening curves at $140^{\circ} \mathrm{C}$ in $\mathrm{Al}-\mathrm{Pb}$ alloys cold rolled 90 pct. The line broadening is the ratio of the integrated intensity and the maximum peak, corrected for back-ground intensity. 


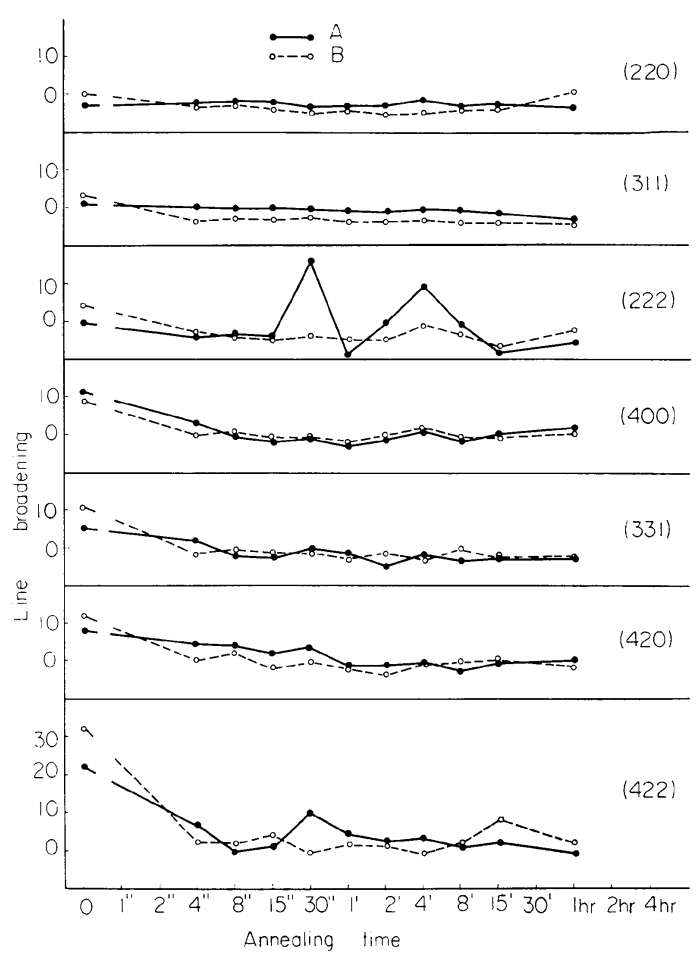

Fig. 5 Line broadening curves at $280^{\circ} \mathrm{C}$ in $\mathrm{Al}-\mathrm{Pb}$ alloys cold rolled 56 pct. The line broadening is the ratio of the integrated intensity and the maximum peak, corrected for back-ground intensity.

\section{4. 考 察}

硬さの減少とともに積分幅が減少するのは転位密度や 歪の平均した值の減少によるものと思われる。(111) 面 はすべり面で転位が一番できやすい面であるために他の 面との間のバランスがはずれて格子面の変動が行なわれ るために変った(222) 面の積分幅があらわれているもの と思われる。

次にできた転位は節で他の転位とバランスを取れば安 定となり消滅しにくくなり転位網としてたまる。その転 位網は面心立方晶においては（112）面といわれている。

（422）面が他の面と変つた積分幅を示すのはそのため のように考えられる。そこで転位が多くできる面は他の 面と変つた積分幅があらわれるようにも考えられるが， これは数学的に証明をするか，他の模型で実験証明をや らねばならない問題である。

\section{5. 総 括}

高純度アルミニウムに原子半径の大きい鉛を添加し， 実験を行なつた結果，次のことがわかつた。

(1) $90 \%$ 圧延の試料の積分幅で，（220）面の幅の減少 具合が高純度アルミニウムのように他の面より非常に速

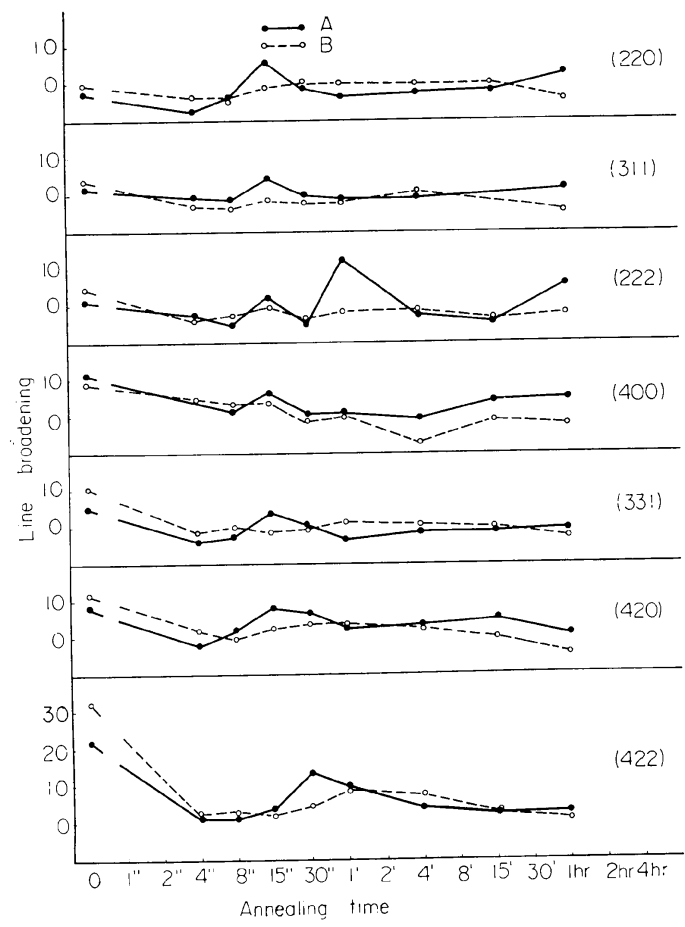

Fig. 6 Line broadening curves at $260^{\circ} \mathrm{C}$ in $\mathrm{Al}-\mathrm{Pb}$ alloys cold rolled 56 pct. The line broadening is the ratio of the integrated intensity and the maxmum peak, corrected for back-ground intensity.

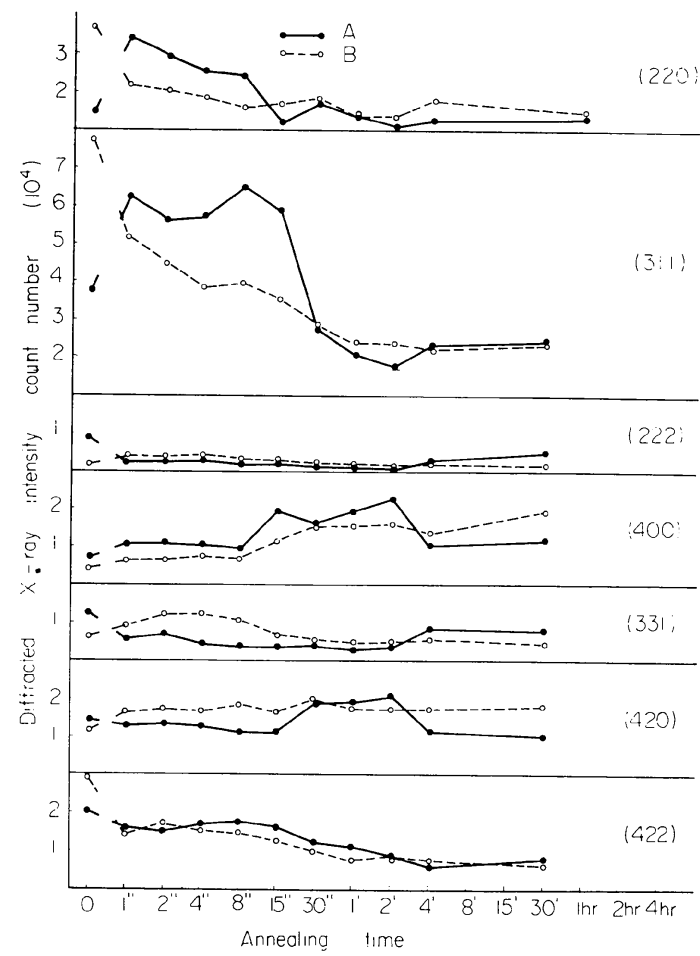

Fig. 7 Diffracted X-ray intensity curves at $140^{\circ} \mathrm{C}$ in $\mathrm{Al}-\mathrm{Pb}$ alloys cold rolled90 pct. 
A

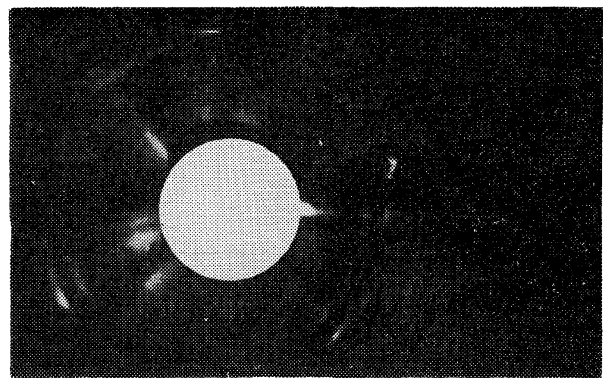

rolled $56 \%$

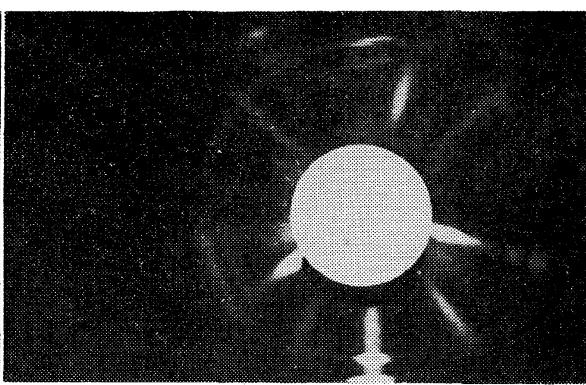

rolled $90 \%$

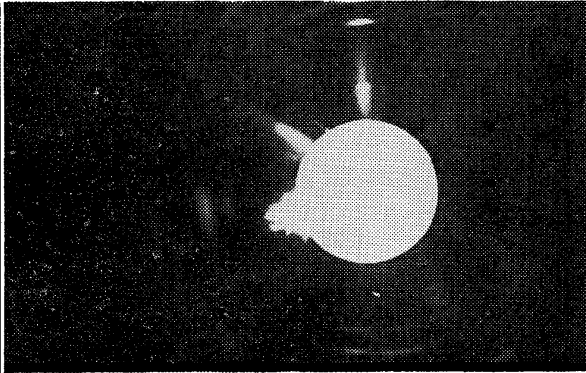

Photo. 2 Debye-Scherrer patterns of as-rolled specimens.

A

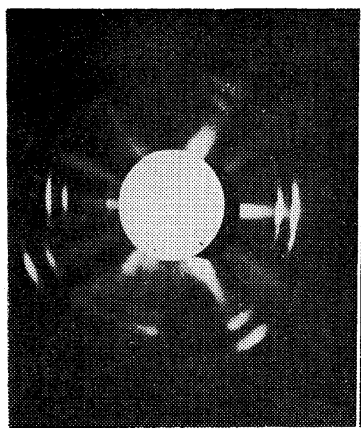

$160^{\circ} \mathrm{C} \quad 4 \mathrm{sec}$

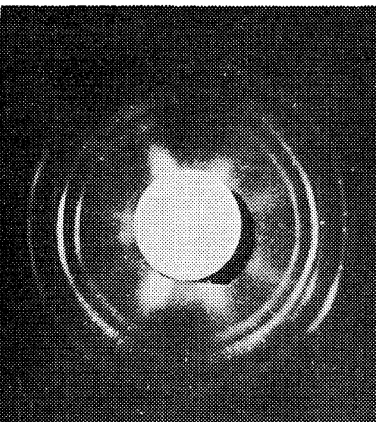

$140^{\circ} \mathrm{C} \quad 4 \mathrm{sec}$.

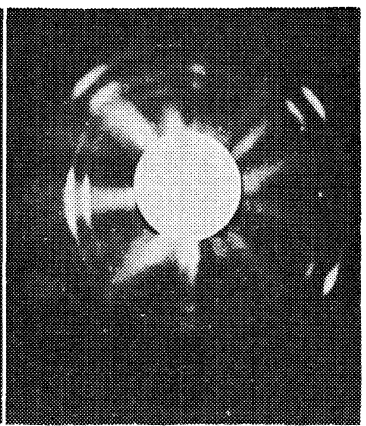

$120^{\circ} \mathrm{C} \quad 4$ sec.
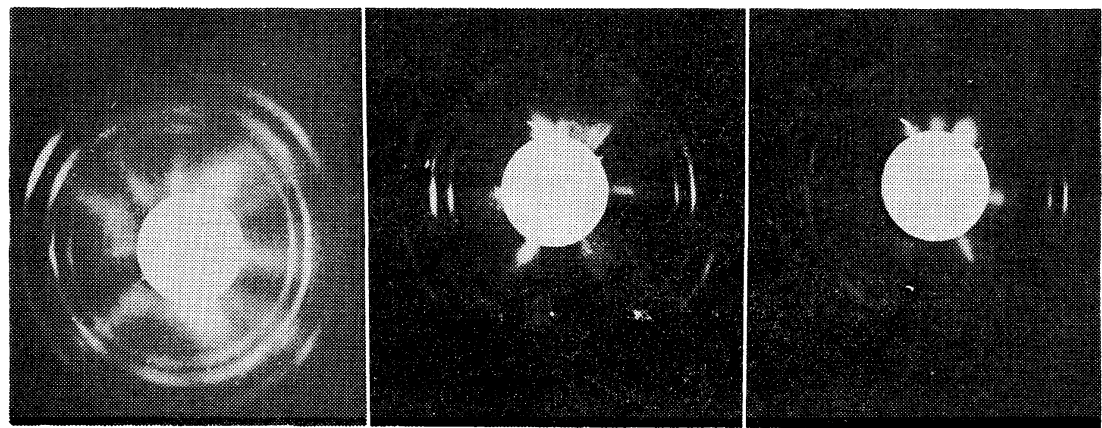

Photo. 3 Debye-Scherrer patterns of specimens cold-rolled $90 \%$ and annealed. 


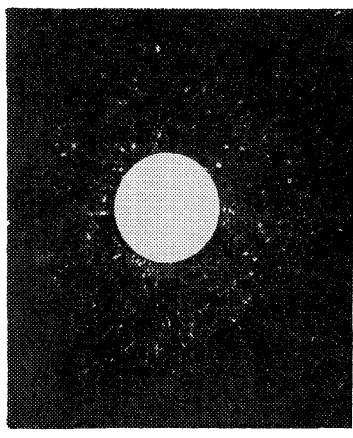

$160^{\circ} \mathrm{C} 30 \mathrm{~min}$.

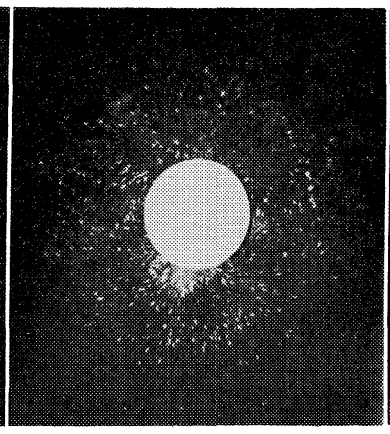

$140^{\circ} \mathrm{C} 30 \mathrm{~min}$.

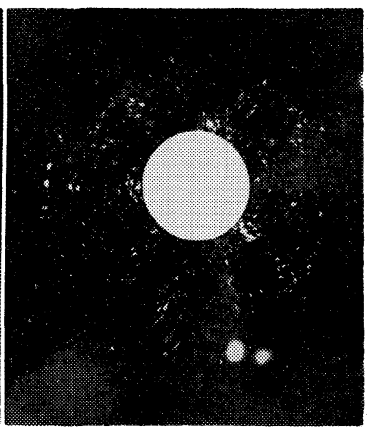

$120^{\circ} \mathrm{G} 2 \mathrm{hr}$.

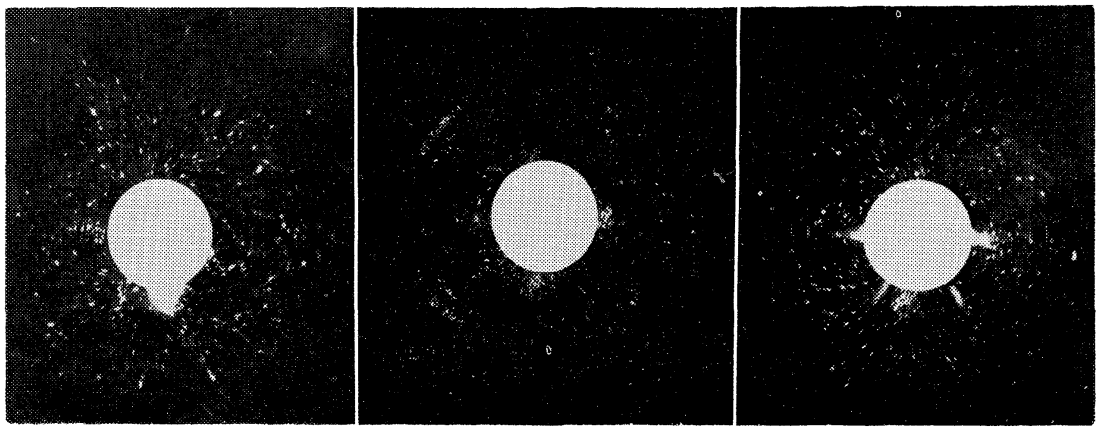

Photo. 4 Debye-Scherrer patterns of specimens cold-rolled $90 \%$ and annealed.

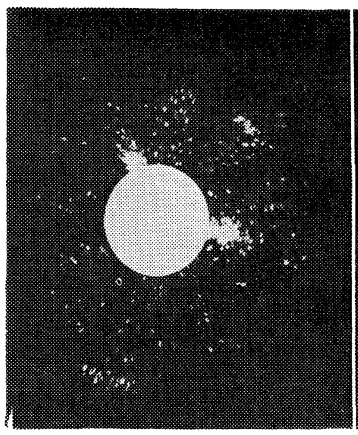

$300^{\circ} \mathrm{C} 4 \mathrm{sec}$.

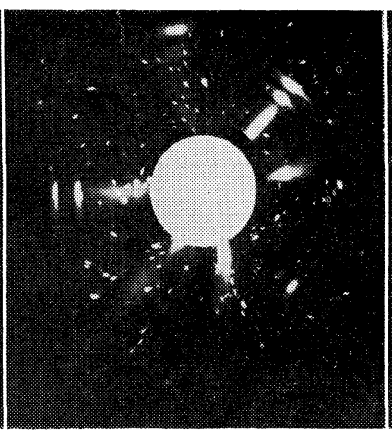

$280^{\circ} \mathrm{C} 4 \mathrm{sec}$.

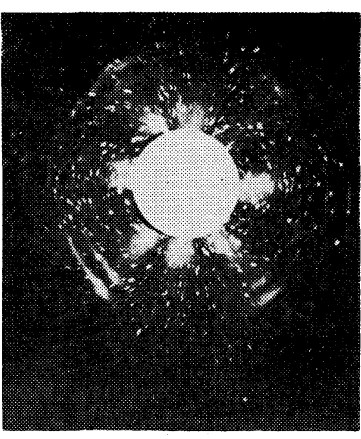

$260^{\circ} \mathrm{C} 4 \mathrm{secl}$.

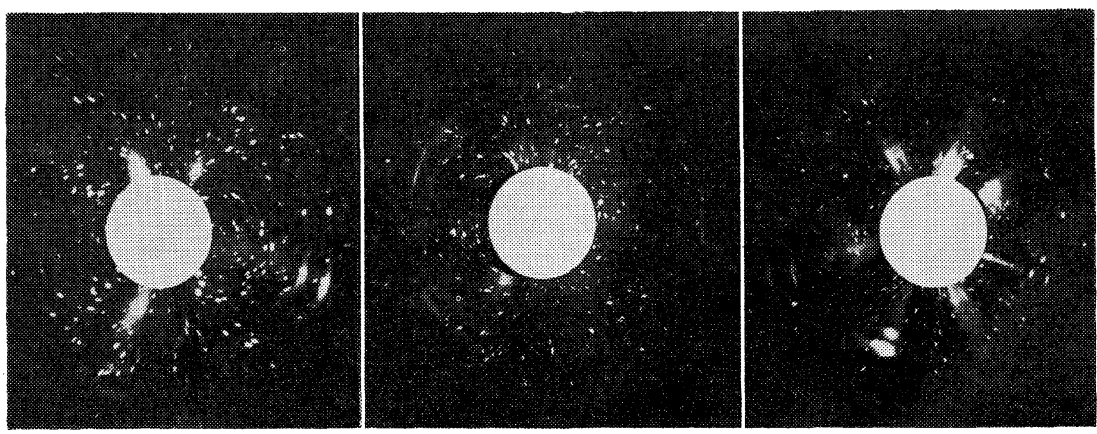

Photo. 5 Dbye-Scherrer patterns of specimens cold-rolled $56 \%$ and annealed. 
く減少することはなかつた。

(2)（222）面の積分幅は高純度アルミニウムと同様に， 時々非常に変つた值があらわれた。

(3）（422）面の積分幅の変化具合が他の面の変化の増 減と時々違つた様子を示した。

（4）積分幅が時々他の面とかわつた変化をする面と転 位が多くできそうな面と合致した。

（5）加工度が増せば再結晶温度が下り，焼なまし温度 が高くなれば再結晶が速くなる原則には変りないが，次 のことが見られた。

i) 高純度アルミニウムとPb添加および添加量の多少 による再結晶温度の変化はほとんど見られないが，压延 材の方向性すなわち積分反射量が少し違う結果となつ た。

ii） $90 \%$ 圧延と $56 \%$ 圧延試料の再結晶に方向性の違い が大きい。

iii） $90 \%$ 圧延と $15 \%$ 圧延の軟化の進み方，組織の変り 方が非常に違つている。

iiii） 65\%圧延の試料では軟化および再結晶の進みかた が, $300^{\circ} \mathrm{C}$ と $280^{\circ} \mathrm{C}$ との差よりも $280^{\circ} \mathrm{C} と 260^{\circ} \mathrm{C}$ との差が非 常に大きかつた。

最後に試料の分析をして頂いた住友軽金属工業(桻に， また実験に協力された藤田勲君に感謝するとともに研究 費の補助を頂いた(財)軽金属奖学会に有難く謝意を表 す。

\section{参 考 文 献}

1) A.H. Lutt \& P. A. Beck: J. Met. 6 (1954) 257; P. Gay, P. B. Hirs ch \& A. Kelly : Acta Met, 1 (1953) 315, F.L. Vogel, JR.: Acta Met 3 (1955) 245; M. J. Hordon \& B.L. Averbach: Acta Met. 9 (1961) 237.

2）五十嵐 勇，五十嵐 全：軽金属 47 (1961) 11 .

\section{質問カードへの解答}

$\mathrm{Pb}$ を選んだ理由は？（麻田）

$\mathrm{Pb}$ は原子半径が大きい。しかし再結晶温度にはたい した影響をあたえない。そこで積分幅にはどのような影 響がでてくるか実験をやつて見ました。

再結晶粒が加工組織を食つて成長して行くものとすれ ば，成長速度の異方性によつて特定の回折線の増加とこ れに対応する他の回折線の減少が見られるはずである。 (小原)

成長する再結晶粒と食われる加工組織の対応が測定で きれば非常に都合がよいのですが残念なことにできませ ん。それは測定方向が代表的 7 つの方向の近くだけです から，測定しない方向も入れまして 8 つの方向の 2 つの 組合せが32通りとなり（加工組織と同じ方向の再結晶組 織が食つて行くのも含まれております), 測定方向の結晶 の増減がわかりましても32通りのどれに対応するかわか りません。また32通りのいくつかが同時に起つているか も知れません。かも知れませんというより 32 通りのうち のいくつかが同時におきているものと考えております。 これらの測定より方向性の違いは違つてでて参りますの で，はつきり方向性が違つているといえると思つており ます。 